\title{
THE RISK OF RE-CHARACTERIZATION OF TITLE TRANSFER FINANCIAL COLLATERAL ARRANGEMENTS
}

\section{Ivan Tot *}

\begin{abstract}
In the European financial markets, the most common types of collateralised transactions are classic repos, sell/buy-backs and securities loans. In them all, financial collateral is provided under the title transfer method: in order to grant the collateral taker with a general right of disposal of collateral, the full legal title to financial collateral is transferred to the collateral taker. The title transfer financial collateral arrangements had prevailed in the European financial markets before the adoption of the Financial Collateral Directive ('FCD'), and they remained dominant after its transposition into the laws of EU Member States. One of the aims of the FCD is to eliminate the so-called recharacterisation of such arrangements as security interests. The FCD is not quite clear on whether its provisions on title transfer financial collateral arrangements are concerned only with the full outright transfers of title or should they also be applied to fiduciary transfers of title. As the fiduciary transfer of title is in substance a form of a security interest, it should not be covered under the notion of title transfer financial collateral arrangement. The ambiguity of the notion of title transfer financial collateral arrangement has spilled over into laws of a couple of Members States, as for instance in the Croatian law. This paper argues that Croatian law extends the scope for possible recharacterisation of title transfer financial collateral arrangements, instead of eliminating the risk of recharacterisation of such arrangements as arrangements creating a security interest in the collateral.
\end{abstract}

KEYWORDS: financial collateral, title transfer financial collateral arrangement, repurchase agreement, repo, sell/buy-back, securities lending, recharacterisation, security interest, fiduciary transfer of title, Financial Collateral Directive

\footnotetext{
Postdoctoral Researcher at Department of Law, Faculty of Economics and Business, University of Zagreb; itot@efzg.hr
} 


\section{INTRODUCTION}

In financial transactions which rely on the financial collateral arrangements, the financial assets which serve as a financial collateral are transferred by the collateral provider to the collateral taker at the opening leg of the transaction, when the agreed principal is transferred by the collateral taker to the collateral provider. At the closing leg of the transaction, when the financial obligations of the collateral provider to the collateral taker have been performed, the equivalent assets to the assets used as financial collateral are transferred by the collateral taker to the collateral provider. In these financial transactions the financial collateral, such as securities and credit claims, serves not only a recovery function but also a tradeability function. ${ }^{1}$ For the collateral taker, it is a commercial imperative that he is allowed to deal freely with the financial collateral prior to the maturity of the obligation to transfer the equivalent assets to the collateral provider. ${ }^{2}$ The traditional security legal structures (such as pledge, charge, and lien) in most jurisdictions are not suitable for realisation of the tradeability function of financial collateral, inasmuch as they commonly do not allow the collateral taker to use and to dispose of the collateral during the ordinary lifetime of the transaction. Hence, two methods of provision of financial collateral were developed in the financial markets: the 'security interest method' that combines a creation of a security interest in favor of the collateral taker with the right of use of financial collateral, and the 'title transfer method' that transfers the full legal title to financial collateral to the collateral taker. ${ }^{3}$

Prior to the adoption of the Financial Collateral Directive ('FCD'), ${ }^{4}$ both of the market developed methods for the provision of financial collateral were

\footnotetext{
1 The financial collateral is used both for recourse in the case of default of the collateral provider (recovery function), and for further trading in the financial market (tradeability function). For a more detailed explanation of the recovery and tradeability functions of financial collateral, see: Keijser, T. R. M. P.: Financial Collateral Arrangements: The European Collateral Directive Considered from a Property and Insolvency Law Perspective, Kluwer, Deventer, 2006, pp. 16-17; Haentjens, M. and de Gioia-Carabellese, P.: European Banking and Financial Law, Routledge, London/New York, 2015, p. 214.
}

2 See: Murray, E.: Financial Collateral Arrangements and the Financial Markets, in: Dahan, F. (ed.), Research Handbook on Secured Financing in Commercial Transactions, Edward Elgar Publishing, Cheltenham/Northampton, 2015, p. 295; Tot, I.: Financial Market lex mercatoria and its Influence on the Financial Collateral Directive, InterEULawEast: Journal for the International and European Law, Economics and Market Integrations, 5 (1) 2018, [DOI: https:// doi.org/10.22598/iele.2018.5.1.3], p. 41.

3 See Keijser, op. cit. (fn. 1), pp. 15-16. See also: Haentjens and de Gioia-Carabellese, op. cit. (fn. 1), pp. 216-217.

4 Directive 2002/47/EC of the European Parliament and of the Council of 6 June 2002 on financial collateral arrangements (OJ L 168, 27/6/2002); hereinafter: FCD. The FCD was 
faced with various legal restrictions in the non-harmonized national laws of the EU Member States. ${ }^{5}$ While national laws were treating financial collateral arrangements that employ the security interest method in the same manner as traditional pledges, the arrangements that employ the title transfer method were met with the risk of recharacterisation of such arrangements as arrangements creating a security interest in the collateral. The legal impediments to the efficient use of the financial collateral were preventing collateral takers to deal freely with the financial collateral provided under both types of the financial collateral arrangements. With the objective to create an EU legal regime for the provision of financial collateral in bilateral financial collateral arrangements, FCD brought on a full harmonisation of substantive rules regarding the use of financial collateral in both the security financial collateral arrangements and the title transfer financial collateral arrangements.

The topics of this paper are the title transfer financial collateral arrangements ('TTFCAs'), the selected provisions of the FCD the purpose of which was to eliminate the risk of recharacterisation of TTFCAs, and the transposition of these provisions into Croatian law. The paper begins with a brief description of the peculiarities of a TTFCA, and of the typical features of the most common types of transactions in the European financial markets that rely on TTFCAs (Chapter 2). Next follows the explanation of the risk of recharacterisation of a TTFCA, and of the factors that can increase this risk (Chapter 3). The paper continues with the analysis of the provisions of FCD directed at the elimination of the risk of recharacterisation of TTFCAs (Chapter 4) and proceeds to the evaluation of the transposition of these provisions into Croatian law (Chapter 5). In the conclusion (Chapter 6), the results of the research are summarized, and the recommendations are given for appropriate amendments of the Croatian Financial Security Act ('FSA'). ${ }^{6}$

amended by: (i) Directive 2009/44/EC of the European Parliament and of the Council of 6 May 2009 amending Directive 98/26/EC on settlement finality in payment and securities settlement systems and Directive 2002/47/EC on financial collateral arrangements as regards linked systems and credit claims (OJ L 146, 10/6/2009); (ii) Directive 2014/59/EU of the European Parliament and of the Council of 15 May 2014 establishing a framework for the recovery and resolution of credit institutions and investment firms and amending Council Directive 82/891/EEC, and Directives 2001/24/EC, 2002/47/EC, 2004/25/EC, 2005/56/EC, 2007/36/EC, 2011/35/EU, 2012/30/EU and 2013/36/EU, and Regulations (EU) No 1093/2010 and (EU) No 648/2012, of the European Parliament and of the Council (OJ L 173, 12/6/2014).

5 See Tot, op. cit. (fn. 2), pp. 55-57.

6 Zakon o financijskom osiguranju [Financial Security Act] (NN no. 76/07, 59/12); hereinafter: FSA. 


\section{TTFCAS: LEGAL STRUCTURE}

Before the adoption of the FCD, the use of the title transfer method in the European financial markets had prevailed over the security interest method of provision of financial collateral, and TTFCAs also remained dominant after the transposition of the FCD into the laws of EU Member States. ${ }^{7}$ In contrast to the security financial collateral arrangement, in a TTFCA the title to the assets used as financial collateral is transferred 'outright' from one party to the other: the transfer of title is an unlimited transfer of all right, title and interest in respect of a financial collateral from the transferor to the transferee. ${ }^{8}$ At the end of the transaction, the transferor discharges the principal debt, while the transferee is obliged to deliver to the transferor assets which are equivalent to the assets used as financial collateral, and not the particular assets which were originally used as financial collateral at the onset of the transaction. This obligation of the transferee is contractual and is owed by the transferee personally, and not proprietary. ${ }^{9}$

The main types of collateralised transactions relying on TTFCAs widespread in the European financial markets are repurchase transactions, sell/buy-back transactions, and securities lending transactions. As all these different types of transactions have similar features and effects, sometimes the term 'repos' is used to refer to all three transaction types together. ${ }^{10}$ In the European market jargon, the term 'repo' is used as a generic term under which only the repurchase transactions and sell/buy-back transactions are covered, ${ }^{11}$ whereas secu-

7 See: Benjamin, J.: Financial Law, Oxford University Press, Oxford/New York, 2007, p. 306; Keijser, op. cit. (fn. 1), p. 100; Mäntysaari, P.: The Law of Corporate Finance: General Principles and EU Law - Volume II: Contracts in General, Springer, Berlin/Heidelberg, 2010, p. 345.

8 See: Benjamin, op. cit. (fn. 7), pp. 306, 317; Keijser, op. cit. (fn. 1), p. 94.

9 See: Benjamin, op. cit. (fn. 7), pp. 317; Bridge, M. and Braithwaite, J.: Private Law and Financial Crises, Journal of Corporate Law Studies, 13 (2) 2013, [DOI: https://doi. org/10.5235/14735970.13.2.361], p. 375; Gretton, G. L.: Financial Collateral and the Fundamentals of Secured Transactions, Edinburgh Law Review, 10 (2) 2008, [DOI: https://doi. org/10.3366/elr.2006.10.2.209], p. 213; Hudson, A.: The Law on Financial Derivatives, Sweet \& Maxwell, London, 2006, p. 476; Murray, op. cit. (fn. 2), p. 316; Tarnanidou, C. I.: EU Financial Collateral Arrangements and Re-Hypothecation in the Shadow of 'Shadow Banking': To Further Regulate or Not?, Journal of Banking Regulation, 17 (3) 2016, [DOI: https://doi. org/10.1057/jbr.2014.22], p. 205.; Yeowart, G. and Parsons, R., with Murray, E. and Patrick, H.: Yeowart and Parsons on the Law of Financial Collateral, Edward Elgar Publishing, Cheltenham/Northampton, 2016, p. 145.

10 See, e. g.: Stadler, V. and Lanoo, K.: The EU Repo Markets: The Need for Full Integration, Centre for European Policy Studies, Brussels, 2000, pp. 9-10.

11 See: Comotto, R.: A Guide to Best Practice in the European Repo Market-ICMA European Repo and Collateral Council - December 2017, International Capital Market Association, 
rities lending transactions are also referred to as "securities loans'"12 and 'stock loans'. ${ }^{13}$ To distinguish repurchase transactions from sell/buy-back transactions, in the European market jargon a repurchase transaction is frequently referred to as 'classic repo', and also as 'US-style repo' or 'all-in repo'. ${ }^{14}$

A repurchase transaction or a classic repo is legally structured as a combination of a spot sale and a forward purchase of securities, both of which are part of a single repurchase agreement: an agreement that the seller will sell securities to the buyer at a certain date at an agreed price, with a simultaneous commitment by the seller to buy equivalent securities from buyer at a future date or on demand at a different price. ${ }^{15}$ Parties commonly enter into a master repurchase agreement under which individual repurchase transactions can be concluded and documented, while the terms and conditions contained in the master repurchase agreement apply to all individual repurchase transactions concluded between them. The standard master agreement most widely used in the European cross-border repo market to document repurchase transactions is the Global Master Repurchase Agreement ('GMRA'). ${ }^{16}$

Zurich, 2017, p. 111. See also: Choudhry, M.: The Repo Handbook, Butterworth-Heinemann, Oxford, 2010, p. 115.

12 See: Benjamin, op. cit. (fn. 7), p. 307; Faulkner, M. C.: An Introduction to Securities Lending, in: Fabozzi, F. J. and Mann, S. V. (eds.): Securities Finance - Securities Lending and Repurchase Agreements, John Wiley \& Sons, Hoboken, 2005, p. 4; Stadler and Lanoo, op. cit. (fn. 10), p. 10.

13 See: Choudhry, op. cit. (fn. 11), p. 127; Lomnicka, E.: Financing Devices Involving the Transfer or Retention of Title, in: Beale, H., Bridge, M., Gullifer, L. and Lomnicka, E.: The Law of Security and Title-Based Financing, Oxford University Press, Oxford, 2018, p. 302.

14 See: Benjamin, op. cit. (fn. 7), p. 307; Choudhry, op. cit. (fn. 11), pp. 115-116; Comotto, loc. cit. (fn. 11); Schindler, C. and Hindelang, M.: Praxishandbuch Repos und Wertpapierdarlehen, Springer Gabler, Wiesbaden, 2016, p. 80.

15 For definition of a repurchase transaction, see also: Benjamin, op. cit. (fn. 7), p. 308; Choudhry, op. cit. (fn. 11), pp. 115-116; Comotto, loc. cit. (fn. 11); Fabozzi, F. J. and Mann, S. V.: Repurchase and Reverse Repurchase Agreements, in: Fabozzi, F. J. and Mann, S. V. (eds.): Securities Finance - Securities Lending and Repurchase Agreements, John Wiley \& Sons, Hoboken, 2005, p. 222; Faulkner, op. cit. (fn. 12), pp. 10-11; Haentjens and de Gioia-Carabellese, op. cit. (fn. 1), p. 211; Keijser, op. cit. (fn. 1), p. 11; Lomnicka, op. cit. (fn. 13), p. 299; Saguato, P.: The Liquidity Dilemma and the Repo Market: A Two-Step Policy Option To Address the Regulatory Void, Stanford Journal of Law, Business, and Finance, 22 (1) 2017, LSE Legal Studies Working Paper No. 21/2015, available at SSRN [https://ssrn.com/abstract=2812173], accessed on 15/09/2018, pp. 27-28; Schindler and Hindelang, loc. cit. (fn. 14); Stadler and Lanoo, op. cit. (fn. 10), p. 9; Tot, op. cit. (fn. 2), pp. 46-47.

16 The current version of the GMRA is: Securities Industry and Financial Markets Association, and International Capital Market Association: Global Market Repurchase Agreement - 2011 version, Washington/Zurich, April 2011; hereinafter: GMRA. 
In a sell/buy-back transaction parties enter simultaneously in a spot sale and a forward purchase as two separate agreements: the seller simultaneously agrees to sell securities to the buyer at a spot price and to buy equivalent securities from the buyer at a forward price. ${ }^{17}$ The sell/buy-back transactions are not necessarily documented under a master agreement, but parties wishing to document their sell/buy-back transactions may do so by supplementing their master repurchase agreement with a separate annex, such as the standard Buy/ Sell Back Annex to the GMRA. ${ }^{18}$

A securities lending transaction is legally structured as a combination of two loan transactions under a single agreement: an agreement that the lender will transfer securities to the borrower at a certain date against the transfer of collateral by borrower to lender, with a simultaneous commitment by the borrower to transfer to the lender equivalent securities at a future date or on demand against the transfer of assets equivalent to collateral to borrower by lender. ${ }^{19}$ The securities lending transactions are typically documented and governed under a master agreement, while the standard master securities lending agreement is the Global Master Securities Lending Agreement ('GMSLA'). ${ }^{20}$

The standard market agreements for all the mentioned types of collateralised transactions contain provisions from which it is evident that the intention of the parties is to transfer the title to the financial assets 'outright' from the transferor to the transferee. Under the GMRA, in a repurchase transaction 'all right, title and interest' in any securities 'shall pass to the party to which the

17 For definition of a sell/buy-back transaction, see also: Benjamin, op. cit. (fn. 7), p. 309; Choudhry, op. cit. (fn. 11), pp. 121-122; Comotto, op. cit. (fn. 11), p. 113; Fabozzi and Mann, op. cit. (fn. 15), p. 237; Faulkner, op. cit. (fn. 12), pp. 11-12; Lomnicka, op. cit. (fn. 13), p. 300; Schindler and Hindelang, op. cit. (fn. 14), p. 95; Stadler and Lanoo, loc. cit. (fn. 10); Tot, op. cit. (fn. 2), p. 53.

18 The current version of the Buy/Sell Back Annex to the GMRA is: Securities Industry and Financial Markets Association, and International Capital Market Association: Global Market Repurchase Agreement (2011 version) - Buy/Sell Back Annex - Supplemental Terms and Conditions for Buy/Sell Back Transactions, Washington/Zurich, March 2012; hereinafter: Buy/ Sell Back Annex to the GMRA.

19 For definition of a securities lending transaction, see also: Benjamin, op. cit. (fn. 7), p. 309; Choudhry, op. cit. (fn. 11), pp. 127-128; Comotto, op. cit. (fn. 11), p. 112; Faulkner, op. cit. (fn. 12), pp. 3-4; Haentjens and de Gioia-Carabellese, op. cit. (fn. 1), p. 212; Keijser, op. cit. (fn. 1), p. 12; Lomnicka, loc. cit. (fn. 13); Schindler and Hindelang, op. cit. (fn. 14), p. 33; Stadler and Lanoo, op. cit. (fn. 10), p. 10; Tot, op. cit. (fn. 2), p. 54.

20 The current version of the GMSLA is: International Securities Lending Association: Global Master Securities Lending Agreement - Version: January 2010 - Update: July 2012, London, 2012; hereinafter: GMSLA. 
transfer is being made'. ${ }^{21}$ A full legal title to securities is transferred outright from the seller to the buyer at the opening leg of the repurchase transaction, while at the closing leg of the repurchase transaction the buyer is obliged to transfer 'equivalent securities', not to return the same securities that were initially transferred to him. ${ }^{22}$ The provisions of the GMRA relating to the transfer of 'all right, title and interest' in securities are also to be applied to sell/buyback transactions if they are documented under the Buy/Sell Back Annex to the GMRA. ${ }^{23}$ The GMSLA also made clear that the transfer of both securities and collateral in a securities lending transaction is an outright transfer of the full legal title to securities and collateral: 'all right, title and interest' in any securities and collateral 'shall pass from one party to the other', while the party acquiring such right, title and interest 'shall have no obligation to return or deliver any of the assets so acquired' and 'shall be obliged [...] to deliver Equivalent Securities or Equivalent Collateral as appropriate'. ${ }^{24}$

\section{RECHARACTERISATION RISK: NOTION, FACTORS AND CONSEQUENCES}

The risk of recharacterisation may be broadly defined as the risk that the court would reject the legal categorisation of a transaction chosen by the parties in their contract, and substitute another. ${ }^{25}$ The recharacterisation of a TTFCA means the treatment under the national law of an outright transfer of title as a security interest in line with the 'actual' intention of the parties to a TTFCA. ${ }^{26}$ In relation to collateralised transactions relying on TTFCAs, recharacterisation risk is particularly associated with repurchase transactions due to the disparity of their legal structure and underlying economics.

\footnotetext{
21 See GMRA, Paragraph 6 (e).

22 See GMRA, Paragraph 1 (a) and 6 (f). Securities are 'equivalent' to the securities initially transferred if they are '(i) of the same issuer; (ii) part of the same issue; and (iii) of an identical type, nominal value, description and [...] amount' as those securities (see GMRA, Paragraph 2 (v)).

23 See: GMRA, Paragraph 1 (b) and (c); Buy/ Sell Back Annex to the GMRA, Paragraph 1 (a) and (b).

24 See GMSLA, Paragraph 4.2.

25 See: Benjamin, op. cit. (fn. 7), p. 322; Gretton, op. cit. (fn. 9), p. 216.

26 See: Choudhry, op. cit. (fn. 11), p. 341; Devos, D.: The Directive 2002/47/EC on Financial Collateral Arrangements of June 6, 2002, in: Vandersanden, G. and De Walsche, A. (eds.): Mélanges en hommage à Jean-Victor Louis - volume II, Editions de l'Université de Bruxelles, Bruxelles, 2003, p. 261; Haentjens and de Gioia-Carabellese, op. cit. (fn. 1), p. 222; Keijser, op. cit. (fn. 1), p. 71; Schindler and Hindelang, op. cit. (fn. 14), p. 165; Stadler and Lanoo, op. cit. (fn. 10), p. 34.
} 
Although the parties to a repurchase agreement agree on an outright transfer of the legal title to securities, the transaction usually functions as an alternative to a secured loan. Most repurchase transactions are for 'general collaterals' or 'GCs' and are cash-driven transactions as the parties are primarily motivated by the need to borrow and lend cash. ${ }^{27}$ At the opening leg of the repurchase transaction, securities are transferred to the buyer against payment of a purchase price, while at the closing leg of the repurchase transaction equivalent securities are transferred to the seller against payment of a higher repurchase price, where the price differential in its economic substance represents an amount of interest. ${ }^{28}$ Despite being legally structured on the basis of the agreement of sale of securities, the underlying economics of cash-driven repurchase transactions is that of a secured loan of cash. ${ }^{29}$

Prior to the adoption of the FCD, the discrepancy between the legal structure and underlying economics of a repurchase transaction had led to legal uncertainty regarding the enforceability of a TTFCA on which repurchase transaction relies. The risk of recharacterisation of a TTFCA as arrangement creating a security interest in collateral was present in several European jurisdictions. It was identified as a legal impediment to the enforceability of TTFCAs mainly in relation to the civil law jurisdictions, ${ }^{30}$ while under the English law it appeared that the agreements made in conformity with the standard market documentation were not subject to recharacterisation risk. ${ }^{31}$

\footnotetext{
27 Repurchase transactions can also be securities-driven transactions, if specific securities, known as 'specials', are in high demand in the market. See: Choudhry, op. cit. (fn. 11), p. 147; Comotto, op. cit. (fn. 11), pp. 86-87; Schindler and Hindelang, op. cit. (fn. 14), p. 83.

28 See: Benjamin, op. cit. (fn. 7), p. 308; Haentjens and de Gioia-Carabellese, op. cit. (fn. 1), p. 217; Keijser, op. cit. (fn. 1), p. 27; Tot, op. cit. (fn. 2), p. 41.

29 See: Benjamin, op. cit. (fn. 7), p. 308; Choudhry, op. cit. (fn. 11), p. 7; Comotto, op. cit. (fn. 11), p. 75; Fabozzi and Mann, op. cit. (fn. 15), p. 222; Haentjens and de Gioia-Carabellese, op. cit. (fn. 1), p. 211; Lomnicka, op. cit. (fn. 13), pp. 301-302; Saguato, op. cit. (fn. 15), p. 30; Yeowart and Parsons, op. cit. (fn. 9), p. 147.

30 'Jurisdictions where there appears to be significant risk of recharacterisation of a title transfer collateral arrangements are Denmark, Finland, Greece, Italy, Netherlands and Spain. It is also not clear to what extent such arrangements may be recharacterised in Luxembourg. In Italy, however, a title transfer arrangement would normally be recharacterised as an irregular pledge (pegno irregolare), which has the effect in substance of transferring title to the pledgee. In Austria and Germany title transfer arrangements will not be recharacterised but certain provisions might mandatorily apply as they would for a security interest.' (International Swaps and Derivatives Association, Collateral Reform Group: Collateral Arrangements in the European Financial Markets - The Need for National Law Reform, International Swaps and Derivatives Association, London, 2000 (hereinafter: ISDA Report), p. 8).
}

31 See: Benjamin, op. cit. (fn. 7), p. 323; ISDA Report, op. cit. (fn. 30), p. 7; Johansson, E.: Property Rights in Investment Securities and the Doctrine of Specificity, Springer, Berlin/Hei- 
The recharacterisation risk was of special concern to the financial market participants, since the TTFCAs had been developed by the market in response to the perfection requirements and the restrictions on the use of collateral by the collateral taker under the traditional security legal structures, so the purpose of the TTFCA would be defeated if it was to be recharacterised as an arrangement creating a security interest in the collateral. ${ }^{32}$ The intention of the parties of a TTFCA is not to create a limited property right in financial collateral, but to transfer the full legal title to the collateral outright on to the collateral taker. The collateral taker becomes the legal 'owner' of the collateral and may use it and dispose of it as he wishes. This tradeability function of the financial collateral which is of major significance to the financial market participants could not be achieved if TTFCAs were to be recharacterised as arrangements creating a security interest in the collateral.

The risk of recharacterisation of a TTFCA is increased by the fact that, although the legal title to the financial collateral is transferred to the collateral taker, the collateral provider retains the economic benefits and risks connected to the financial collateral. This is evidenced by the contractual rights and obligations of the parties to a repurchase agreement or a security lending agreement relating to income payments and margin maintenance. The collateral taker as the acquirer of the legal title to collateral is entitled to interest, dividends and any other earnings on the collateral, yet he is contractually obliged to pay to the collateral provider a so-called 'manufactured dividend': an amount equal to such income payment. ${ }^{33}$ Margin maintenance methods are used in order to maintain the originally set balance between the market value of financial collateral and the value of counter-performance provided for financial collateral at the beginning of the transaction. Prime example of a margin maintenance method is a margin transfer: simplified, in the case of downward price fluctuations of the transferred collateral the collateral taker may require the collateral provider to deliver additional securities; while in the case of upward price fluctuations of the transferred collateral the collateral provider may require the collateral taker to deliver additional cash. ${ }^{34}$ The party who has received the margin is obliged to transfer the equivalent margin at the end of the

delberg, 2009, p. 87; Keijser, op. cit. (fn. 1), p. 134; Lomnicka, op. cit. (fn. 13), p. 302.; Yeowart and Parsons, op. cit. (fn. 9), p. 150.

32 See: Benjamin, op. cit. (fn. 7), p. 322; Choudhry, op. cit. (fn. 11), p. 346; ISDA Report, op. cit. (fn. 30), p. 7; Keijser, op. cit. (fn. 1), p. 71.

33 For income payments under GMRA, see: GMRA, Paragraph 5 (a) - (b). For income payments under GMSLA, see: GMSLA, Paragraph 6.2 - 6.3.

34 For margin maintenance methods under GMRA, see: GMRA, Paragraph 4 (a) - (1). For margin maintenance methods under GMSLA, see: GMSLA, Paragraph 5.4 - 5.8. 
transaction, while both transfers of margin and equivalent margin are outright transfers of the full legal title to the margin, ${ }^{35}$ thus serving both a security and a tradeability function.

Recharacterisation risk relating to TTFCAs is also increased by the language used by the financial market participants themselves since the market jargon employs terminology which is more associated with secured lending than with the true sales. For example, in the repo market jargon, the term 'collateral' is used to refer to the securities sold at the opening leg of the repurchase transaction, although these are not collateral in the traditional legal sense of the term as the full legal title to them is transferred outright to the buyer. ${ }^{36}$ The standard market documentation relating to TTFCAs avoids phrases that would imply a secured loan. The term 'collateral' is not used in the GMRA, which clarifies that the expressions used in the GMRA which are commonly associated with secured loans are used only to reflect terminology used in the market, and that, notwithstanding the use of those expressions, 'all right, title and interest in and to' the transferred securities 'shall pass to the transferee'. ${ }^{37}$ In the same manner, GMSLA provides that the expressions such as 'borrow', 'lend' and 'collateral' are used in the GMSLA to reflect the market terminology and that, notwithstanding the use of those expressions, the title to "borrowed" or "lent" securities and to collateral 'shall pass from one Party to another [...], the Party obtaining such title being obliged to deliver Equivalent Securities or Equivalent Collateral as the case may be'. ${ }^{38}$

Thus a risk of recharacterisation of repurchase transactions, sell/buy-back transactions and securities lending transactions appear to be minimal if the parties to agreements governing those transactions do not deviate from the terms of the standard market documentation. The risk is increased if the parties amend the standard master agreement with the provisions which can make their repurchase agreement or securities lending agreement to be internally inconsistent. Examples for such provisions in a repurchase agreement are provisions which limit the buyer's right to deal freely in the securities during the term of the repurchase transaction, which require the buyer to deliver identical securities or which allow the seller to substitute the securities without the consent of the buyer. ${ }^{39}$

\footnotetext{
See: GMRA, Paragraph 6 (e); GMSLA, Paragraph 4.2.

See: Comotto, op. cit. (fn. 11), pp. 75, 94; Keijser, op. cit. (fn. 1), pp. 19-20.

37 See GMRA, Paragraph 6 (f).

38 See GMSLA, Paragraph 2.3.

39 See: Benjamin, op. cit. (fn. 7), p. 323; Choudhry, op. cit. (fn. 11), p. 348; Johansson, op. cit. (fn. 31), p. 4; Keijser, op. cit. (fn. 1), p. 134.
} 


\section{THE FCD: ELIMINATING THE RISK OF RECHARACTERISATION OF TTFCAS}

The objective of the FCD was to create an EU legal regime for the provision of financial collateral under bilateral financial collateral arrangements, including TTFCAs..$^{40}$ One of its explicit aims is to protect the validity of TTFCAs. ${ }^{41}$ The FCD is to be applied to TTFCAs irrespective of whether or not they are governed by a master agreement. ${ }^{42}$ The application of the FCD to TTFCAs is subject to the following requirements: (i) both parties must belong to one of the categories defined in the $\mathrm{FCD}{ }^{43}$ (ii) financial collateral must consist of cash, financial instruments or credit claims; ${ }^{44}$ (iii) financial collateral has to be provided to the collateral taker; ${ }^{45}$ (iv) the provision of financial collateral has to be evidenced in writing or in a durable medium; ${ }^{46}$ (v) TTFCA has to be evidenced in writing or in a legally equivalent manner. ${ }^{47}$

A TTFCA is defined in the FCD as 'an arrangement, including repurchase agreements, under which a collateral provider transfers full ownership of, or full entitlement to, financial collateral to a collateral taker for the purpose of securing or otherwise covering the performance of relevant financial obligations. ${ }^{48}$

The definition of a TTFCA includes an explicit reference to the repurchase agreement, i.e. the agreement governing a repurchase transaction. This reference is probably made due to the disparity between legal structure and underlying economics which is more intrinsic to repurchase transactions than to the other types of financial transactions that rely on TTFCAs. Also, the peculiar feature of a repurchase transaction is that the securities which are sold to the buyer at the onset of the transaction are referred to as 'collateral' in the financial market practice, although they are in fact the main object of that sale agreement and not the additional collateral provided to secure the obligation relating to the main object of the agreement. Therefore, the clear

\footnotetext{
See: FCD, Recital (3), as well as Articles 1 (1), and 2 (1) (a).

See FCD, Recital (13).

See FCD, Article 2 (1) (a).

For the personal scope of application, see FCD, Article 1 (2) and (3).

44 See: FCD, Recital (18), as well as Articles 1 (4), and 2 (1) (d), (e), (o).

45 See FCD, Recital (10) and Article 1 (5), subparagraph 1.

46 See FCD, Recital (10) and Article 1 (5), subparagraphs 1-3.

47 See FCD, Recital (11) and Article 1 (5), subparagraph 4.

48 See FCD, Article 2 (1) (b).
} 
mention of the repurchase agreement in the definition of a TTFCA is more than welcome. ${ }^{49}$

The notion of 'relevant financial obligations' contained in the definition of a TTFCA is also defined by the FCD. For the purpose of FCD, 'relevant financial obligations' are 'the obligations which are secured by a financial collateral arrangement and which give a right to cash settlement and/or delivery of financial instruments'. ${ }^{50}$

In the definition of a TTFCA, the FCD employs the term 'ownership', yet the use of this term is not entirely fitting, especially in relation to the book-entry securities. ${ }^{51}$ The essential element of the definition of a TTFCA is the transfer of 'full ownership' of, or 'full entitlement' to, financial collateral. The words 'full ownership' and 'full entitlement' are used to indicate that the notion of a TTFCA covers an 'outright' transfer of title to financial collateral, i.e. the transfer of all right, title and interest in the financial collateral. This is particularly made clear in the German version of the FCD where a TTFCA is referred to as 'financial collateral in the form of full right transfer' (Ger. Finanzsicherheit in Form der Vollrechtsübertragung) and defined as 'the complete assignment of a financial asset or the transfer of all rights'. ${ }^{52}$ Under a TTFCA there is no creation of a security interest in the financial collateral, and the collateral taker's 'ownership' of financial collateral is unlimited. Thus the tradeability function of financial collateral under a TTFCA is guaranteed by the FCD and the collateral taker may use and dispose of financial collateral as he wishes. In contrast to TTFCA, in a security financial collateral arrangement, the financial collateral is provided 'by way of security' and the 'full ownership of the financial collateral remains with the collateral provider'. ${ }^{53}$ In order to ensure the tradeability function of financial collateral under a security financial collateral arrangement, the FCD requires the Member States to entitle the collateral taker with the controversial 'right of use' of financial collateral. ${ }^{54}$

49 Due to several mentions of 'repurchase agreement' in the text of the FCD (see also Recitals (3), (13) and (14)), it was noted in the literature that a better name for the FCD 'might have been the "Repo Protection Directive"': Gretton, op. cit. (fn. 9), p. 210.

50 See FCD, Article 2 (1) (f).

51 See: Keijser, op. cit. (fn. 1), p. 96; Gretton, op. cit. (fn. 9), p. 214-215.

52 Ger. die vollständige Übereignung bzw. Zession eines Finanzaktivums oder die Übertragung aller Rechte.

53 See FCD, Article 2 (1) (c).

54 See FCD, Article 5 (1). For a detailed analysis of the notion and purpose of a 'right of use' in relation to financial collateral in security financial collateral arrangements, see especially: Keijser, op. cit. (fn. 1), pp. 175-274. 
It seems that the use of the words 'securing or otherwise covering' in the definition of a TTFCA in the FCD has misled several authors to the conclusion that the definition of a TTFCA also covers arrangements which create a security interest in the financial collateral. ${ }^{55}$ However, the words 'securing or otherwise covering' are employed in the definition of a TTFCA to describe only the purpose of a TTFCA, not the method for provision of financial collateral under a TTFCA. ${ }^{56}$ TTFCA's use the title transfer method of provision of financial collateral, not the security interest method. The word 'securing' is not used in the definition of a TTFCA in a technical legal sense and does not mean a creation of a security interest. ${ }^{57}$ Since a TTFCA has a comparable economic effect to security but does not involve the creation of a de jure security interest, it is sometimes described in the literature as 'quasi-security'. 58

The accuracy of the above analysis is confirmed in the Recital (13) of the FCD which establishes the elimination of recharacterisation risk relating to TTFCAs as one of the principal aims of the FCD. In the Recital (13) the FCD explicitly provides: 'This Directive seeks to protect the validity of financial collateral arrangements which are based upon the transfer of the full ownership of the financial collateral, such as by eliminating the so-called re-characterisation of such financial collateral arrangements (including repurchase agreements) as security interests.'

With the purpose to eliminate the recharacterisation risk of TTFCAs, the Article 6 (1) of the FCD requires the Member States to ensure that a TTFCA 'can take effect in accordance with its terms'. ${ }^{59}$ This provision of the FCD requires the Member States to recognise the validity of TTFCAs and to ensure their enforceability. The Member States are required to give full effect to those contractual provisions of agreements governing the financial transactions which rely on TTFCAs that envisage the full unlimited title transfer of financial collateral. ${ }^{60}$ Such provisions are, e.g., the provisions of Paragraph 6 (e) of the GMRA and of Paragraph 4.2 of the GMSLA. It would be contrary to the Article 6 (1) of the FCD if a Member State would treat a TTFCA in its national laws and regulations as arrangement creating a security interest, or if

\footnotetext{
55 See, e. g., Gretton, op. cit. (fn. 9), p. 218.

56 See: Murray, op. cit. (fn. 2), p. 286; Yeowart and Parsons, op. cit. (fn. 9), p. 152.

57 See Yeowart and Parsons, op. cit. (fn. 9), p. 153.

58 See: Benjamin, op. cit. (fn. 7), p. 307; Lomnicka, op. cit. (fn. 13), p. 301; Murray, op. cit. (fn. 2), p. 288

59 See FCD, Article 6 (1).

60 See: Devos, op. cit. (fn. 26), p. 268; Keijser, op. cit. (fn. 1), p. 160; Yeowart and Parsons, op. cit. (fn. 9), p. 147.
} 
a national court would in the course of proceedings recharacterise the transfer of title to the financial collateral under a TTFCA as a creation of a security interest in the financial collateral.

With several other provisions of the FCD relating to the TTFCAs, the FCD seeks to ensure efficient creation, perfection, and enforcement of a TTFCA. The Article 3 (1) of the FCD imposes an obligation of the Member States to 'not require that the creation, validity, perfection, enforceability or admissibility in evidence of a financial collateral arrangement or the provision of financial collateral under a financial collateral arrangement be dependent on the performance of any formal act'. Article 6 (2) of the FCD seeks to protect the enforceability of bilateral close-out netting as a means of enforcement of TTFCAs. Moreover, FCD aims at ensuring that the TTFCAs, and the close-out netting provisions contained in them, remain valid and enforceable notwithstanding the opening of insolvency proceedings against the collateral taker or collateral provider. ${ }^{61}$ Also, FCD calls for a disapplication of several provisions of national insolvency law, such as the 'zero hour' rules and the 'suspect period' rules, which were considered to be an obstacle for effective realisation of financial collateral. ${ }^{62}$

Due to the significant reception in the FCD of the terminology used in the financial markets and of the legal structures developed in the financial markets, the proper transposition of the FCD into national laws of the Member States was exceptionally challenging. As noted by a prominent legal scholar, the FCD 'is notoriously difficult to interpret'. ${ }^{63}$ Therefore, it does not come as a surprise that in the several Member States the TTFCAs were, under national laws set forth in transposition of the FCD, considered as security interest arrangements, contrary to the Article 6 (1) of the FCD. ${ }^{64}$

\footnotetext{
${ }^{61}$ See FCD, Articles 4 (5) and 7 (1).

62 See FCD, Article 8 (1), (2) and (3). The 'zero-hour' rules give a declaration of insolvency the retroactive effect from the beginning of the day on which the insolvency is declared, while the 'suspect period' rules enable the liquidator to avoid transactions entered into during the 'suspect period' leading to the insolvency order. See, e. g., Keijser, T. R. M. P.: A Need for a Change: The Undesirable Consequences of the Settlement Finality Directive and the Collateral Directive in the Field of Property and Insolvency Law, in Particular for Small- and Medium-Sized Enterprises, Zeitschrift für Europäisches Privatrecht, 13 (2) 2006, [DOI: http:// dx.doi.org/10.2139/ssrn.2859451], pp. 318-320.

63 See: Beale, H.: A View from England (Symposium: Reform of Security over Moveable Property), Edinburgh Law Review, 16 (2) 2012, [DOI: https://doi.org/10.3366/elr.2012.0106], p. 282.

64 For instance, in Sweden, the assumption was made in the governmental reports that repos should be characterised as 'security transfers' (see: Johansson, op. cit. (fn. 31), p. 189).
} 
Since the English version of the FCD employed the term 'transfer of the full ownership' in relation to TTFCAs, the FCD left room for possible interpretation of provisions of Article 2 (1) (b) and Article 6 (1) in a way that the notion of TTFCA under the FCD covers not only outright transfers of title but also fiduciary transfers of title. Fiduciary transfers of title are also transfers of the 'full ownership', but unlike the outright transfers of the title, they are not unlimited transfers of title. The view that the fiduciary transfers of title are covered under the notion of a TTFCA in the FCD is proposed by several authors in the legal literature who not only identify the TTFCA with the fiducia cum creditore, but moreover present the inclusion of fiduciary transfers of title in the FCD as an important novelty for those European property law systems that contain a general prohibition of fiducia cum creditore. ${ }^{65}$

The opposing view is that the notion of TTFCA under the FCD should cover only financial collateral arrangements that fulfill both the recovery and the tradeability function of financial collateral and not the arrangements that essentially entail the establishment of a security interest. ${ }^{66}$ The tradeability function is what substantially distinguishes a TTFCA from traditional security legal structures, such as pledge and fiduciary transfer of title, under which the collateral taker would be able to dispose of the financial collateral only in the event of default of collateral provider ${ }^{67}$ Since on the basis of a fiduciary agreement the collateral taker does not have the right to dispose of the collateral under normal circumstances, where no default has taken place, the tradeability function of financial collateral is not present and the fiduciary transfer of title is actually a security interest. ${ }^{68}$ Therefore, only outright transfers of the title should be covered by the notion of a TTFCA and protected under Article 6 (1) of the FCD, whereas the agreements employing a fiduciary transfer of title to collateral which are intended only for recovery purposes should be considered as security financial collateral agreements. This interpretation is compatible with the provisions of the standard market agreements which govern the main

\footnotetext{
65 See, e. g.: Akkermans, B.: The European Union Development of European Property Law, in: Godt, C. (ed.), Cross Border Research and Transnational Teaching under the Treaty of Lisbon - Hanse Law School in Perspective, Wolf Legal Publishers, Oisterwijk, 2010, p. 44; Gretton, op. cit. (fn. 9), pp. 217, 222; Lefter, C. and Duagi, G.: The Fiduciary Guarantee in the Romanian and European Legal Context, Juridical Tribune, 6 (2) 2016, pp. 109-110; Moreno, H. S.: Towards a European System of Property Law, European Review of Private Law, 19 (5) 2011, p. 589; Sigman, H. C. and Kieninger, E.: The Law of Assignment of Receivables: in Flux, Still Uncertain, Still Non-Uniform, in: Sigman, H. C. and Kieninger, E.: Cross-Border Security over Receivables, Sellier, Munich, 2009, p. 5.

66 See Keijser, op. cit. (fn. 1), p. 162.

67 See ibid, p. 133.

68 See ibid, p. 161.
} 
types of financial transactions that rely on TTFCAs ${ }^{69}$ and is in line with the economic, liquidity-enhancing function that financial collateral fulfills. ${ }^{70}$

The view that the notion of a TTFCA under the FCD covers outright transfers of title and not the fiduciary transfers of title to financial collateral is supported with the Article 6 (2) of the FCD which refers to the obligation of the collateral taker to transfer 'equivalent collateral', not the identical financial collateral originally provided by the collateral provider at the beginning of the transaction. The collateral taker's right of use and dispose of financial collateral provided under a TTFCA is inherent to the outright transfer of title to financial collateral. The protection of the collateral providers in transactions that rely on TTFCAs is ensured with the provisions of Securities Financing Transactions Regulation ('SFTR') ${ }^{71}$ which provides that the collateral taker's right to reuse of financial collateral is subject to the two conditions: (i) that the collateral provider has been duly informed in writing by the collateral taker of the risks and consequences of concluding a TTFCA, at least those that may arise in the event of the default of the collateral taker; (ii) that the collateral provider has expressly agreed to provide collateral by way of a TTFCA. ${ }^{72}$

\section{CROATIAN FSA: EXTENDING THE SCOPE FOR RECHARACTERISATION OF TTFCAS}

Repurchase transactions, sell/buy-back transactions and securities lending transactions are types of securities financing transactions ('SFT's) regularly entered into by the participants in the Croatian financial market. In the SFT segment of the Croatian financial market, the repo market is considered to be particularly developed. ${ }^{73}$ Domestic repurchase transactions are commonly governed under the Standard Master Repo Agreement (Cro. Okvirni repo ugovor; 'ORU'), prepared and published by the two national financial market associations. ${ }^{74}$ The ORU was heavily influenced by the provisions of the

\footnotetext{
69 See supra, Chapter 2.

70 See Keijser, op. cit. (fn. 1), p. 162.

71 Regulation (EU) 2015/2365 of the European Parliament and of the Council of 25 November 2015 on transparency of securities financing transactions and of reuse and amending Regulation (EU) No 648/2012 (OJ L 337, 23/12/2015); hereinafter: SFTR.

72 See SFTR, Article 15 (1).

73 For the size and the structure of the Croatian repo market, see: Mihalina, E.: Ekonomski aspekti repo posla, in: Slakoper, Z. (red.), Bukovac Puvača, M. and Mihelčić, G. (eds.): Bankovni i financijski ugovori, Narodne novine, Zagreb, 2017, pp. 1288-1291.

74 ACI Croatia/Hrvatska udruga banaka: Okvirni ugovor o reotkupu financijskih instrumenata (okvirni repo ugovor) - verzija 2014, ACI Croatia/Hrvatska udruga banaka, Zagreb, 2014; hereinafter: ORU.
} 
GMRA and represents almost a letter-by-letter translation of the GMRA into the Croatian language. In a similar manner as the GMRA, the ORU provides that the transfer of financial instruments in a repurchase transaction governed by the ORU is the transfer of 'all rights' to financial instruments and that the transferee is obliged to deliver the 'equivalent' financial instruments at the end of the transaction. ${ }^{75}$ Sell/buy-back transactions may be documented by supplementing the ORU with a separate annex, ${ }^{76}$ which is similar to the Buy/Sell Back Annex to the GMRA. There is no specific standard market agreement for securities lending which would be comparable to the GMSLA, but a standard market agreement for derivatives transactions may be used to document the securities lending transactions. ${ }^{77}$

The repurchase agreement, the sell/buy-back agreement and the securities lending agreement are not regulated as specific types of contract in the Croatian Obligation Act ('COA'). ${ }^{78}$ From the contract law point of view, a repurchase agreement under Croatian law is a mixed contract consisting of elements of two sale agreements, one of which is a spot sale of securities, and the other being a forward purchase of securities. ${ }^{79}$ In a sell/buy-back transaction, parties simultaneously enter in a spot sale and a forward purchase of securities as two separate agreements of sale. ${ }^{80}$ Securities lending agreement is a combination of two loan agreements, one being the loan of the principal securities, while the other is the loan of collateral securities or cash. ${ }^{81}$

Under Croatian law, the provision of securities on the basis of a valid repurchase agreement, if the parties do not deviate from the provisions of ORU, will lead to an outright transfer of title to provided securities. ${ }^{82}$ An outright transfer of title is also the result of the provision of principal securities and of the collateral on the basis of a valid securities lending agreement since in

\footnotetext{
75 See ORU, Paragraphs 11.1., and 11.2.

76 ACICroatia/Hrvatska udruga banaka: Dodatak IOkvirnog ugovora o reotkupu financijskih instrumenata (okvirnog repo ugovora) - verzija 2014, ACI Croatia/Hrvatska udruga banaka, Zagreb, 2014.

77 See: ACI Croatia/Hrvatska udruga banaka: Okvirni ugovor za transakcije izvedenim financijskim instrumentima - verzija 2008, ACI Croatia/Hrvatska udruga banaka, Zagreb, 2008.

78 Zakon o obveznim odnosima [Obligations Act] (NN no. 35/05, 41/08, 125/11, 78/15, 29/18); hereinafter: COA.

79 See Tot, I.: Repo ugovor, in: Slakoper, Z. (red.), Bukovac Puvača, M. and Mihelčić, G. (eds.): Bankovni i financijski ugovori, Narodne novine, Zagreb, 2017, pp. 1254-1255.

80 See ibid, pp. 1248-1249.

$81 \quad$ See ibid, p. 1251.

82 See COA, Article 376 (1) and (2).
} 
the course of a securities lending transaction the principal securities and the collateral are transferred on the basis of a loan of fungibles. ${ }^{83}$ The securities used in repurchase transactions and securities lending transactions are commonly fixed-income instruments, such as bonds, and equity securities, such as ordinary shares. They are typically non-materialized securities, the title to which is normally acquired in the moment of the book-entry into the acquirer's account in the central securities depository. ${ }^{84}$

As well as in the European cross-border financial market, in the Croatian financial market repurchase transactions, sell/buy-back transactions and securities lending transaction employ a title transfer method for provision of financial collateral and are types of transactions which rely on TTFCAs within the meaning employed in the FCD. Transposition of the FCD into Croatian law was made through provisions of FSA which is marked by clumsy translations of the market originated terminology and by several inconsistencies and contradictions.

Croatian FSA employs the term 'financial security' (Cro. financijsko osiguranje) to refer to the method of provision of a financial collateral, whereas the financial collateral is referred to as a 'financial security instrument' (Cro. instrument financijskog osiguranja). ${ }^{85}$ Financial security is defined as 'a transfer of, or an establishment of a special right of pledge in, financial security instruments for the purpose of securing a financial obligation'. ${ }^{86}$ A financial collateral agreement is referred to as 'financial security agreement' and is defined in Article 2, pt. 2 of the FSA which represents an unsuccessful attempt to describe both the TTFCAs and the security financial collateral arrangements in a single definition. In relation to the TTFCAs, the relevant elements of this definition of 'financial security agreement' are that the financial security agreement is an agreement under which: (i) the provider of a financial security instrument is obliged to transfer a financial security instrument to the taker of a financial security instrument, (ii) for the purpose of securing the performance of own financial obligation or financial obligation of another, (iii) under conditions set

83 See COA, Article 499 (2). For transfer of title on the basis of loan of fungibles in Croatian law, see: Slakoper, Z.: Ugovor o zajmu, in: Slakoper, Z. (red.), Bukovac Puvača, M. and Mihelčić, G. (eds.): Bankovni i financijski ugovori, Narodne novine, Zagreb, 2017, pp. 531-532.

84 See Zakon o tržištu kapitala [Capital Market Act] (NN no. 65/18), Article 530 (1). For a detailed analysis of the acquisition of non-materialised securities under Croatian law, see: Markovinović, H. and Tepeš, N.: Posebno o pripadnosti nematerijaliziranih vrijednosnih papira povjerenih u skrbništvo, in: Slakoper, Z. (red.), Bukovac Puvača, M. and Mihelčić, G. (eds.): Bankovni i financijski ugovori, Narodne novine, Zagreb, 2017, pp. 985-989.

85 See FSA, Articles 1 and 2, pt. 1.

86 See FSA, Article 2, pt. 1. 
out in the agreement, master agreement or a general terms and conditions, (iv) while the taker of that financial security instrument is obliged, in accordance with the contractual terms and provision of FSA and other laws, to return to the provider 'the same or equivalent' financial security instrument.

An attempt to describe a TTFCA is also made in Article 2, pt. 7 of the FSA. The problem with this provision is that it refers to a 'security by transfer of financial security instrument' (Cro. osiguranje prijenosom instrumenta financijskog osiguranja), which is a method of provision of financial collateral, and not the agreement which employs a method of provision of financial collateral. Yet the method of provision of financial collateral is here defined as 'financial collateral agreement under which the rights in financial security instrument are transferred from the provider to the taker of a financial security instrument, including a repurchase agreement and a reverse repurchase agreement' ${ }^{87}$

Article 6 (1) of the FCD, which sanctions the enforceability of TTFCAs and intends to eliminate the recharacterisation risk, is transposed in the FSA with the provision which reads as follows: 'If not stipulated otherwise in the financial security agreement under which the financial security instrument is transferred, the taker of a financial security instrument is entitled to unlimited use and dispose of the cash and financial instruments which are financial security instruments, including to a right to sell them. ${ }^{98}$

The use of words 'unlimited use and dispose of' (Cro. koristiti se $i$ raspolaga$t i$ ) in the Article 6 (1) of the FSA indicates that the transfer of title in a TTFCA under Croatian law is an outright transfer of title, i.e., that all right, title and interest to financial collateral is transferred to the collateral taker. Thus, the tradeability function of financial collateral in a TTFCA is in Croatian law guaranteed and clearly highlighted. However, by its legal nature, the provision of Article 6 (1) is a non-mandatory provision. Therefore, the parties to a TTFCA may agree that the collateral taker will not be entitled to unlimited use and dispose of financial collateral, or that his rights to use and dispose of financial collateral will be limited and subject to conditions laid down in the agreement. Such contractual provisions would be in contradiction with the dual purpose of financial collateral under a TTFCA and would indicate that the parties intended the financial collateral to serve only a recovery purpose. ${ }^{89}$

\footnotetext{
87 For a justly criticism of this provision see: Radin, D.: Hrvatski pravni okvir financijskog osiguranja, in: Miladin, P. and Jakšić, T. (eds.): Prilagodba hrvatskog prava i ekonomije europskom tržištu kapitala, Pravni fakultet Sveučilišta u Zagrebu, Zagreb, 2013, pp. 344-345; Tot, op. cit. (fn. 79), p. 1253.

88 See FSA, Article 6 (1).

89 See: Radin, op. cit. (fn. 87), pp. 345-346; Tot, op. cit. (fn. 79), p. 1258.
} 
The non-mandatory nature of Article 6 (1) of the FSA is of a special concern when this provision is considered in connection with Article 2, pt. 2 of the FSA. In contrast to the definition of TTFCA set out in the Article 2 (1) (b) of the FCD, in relation to the purpose of a TTFCA the Article 2, pt. 2 of the FSA provides that the title to financial collateral is transferred for the purpose of 'securing' financial obligations, while the words 'or otherwise covering' are omitted from the FSA. Moreover, instead of referring to the obligation of collateral taker to provide only the 'equivalent' financial collateral to the collateral provider at the end of the transaction, the Article 2, pt. 2 of the FSA opts for a solution according to which the collateral taker may also be obliged to return to the collateral provider the 'same' financial collateral that was originally provided to him at the beginning of the transaction. ${ }^{90}$ The contractual provision which would require the collateral taker to provide the collateral provider with the same financial collateral that was previously delivered to the collateral taker is a prime example of a provision that indicates that the actual intention of the parties might have been a creation of a security interest in the financial collateral. The consequence of the gold-plating of the FCD, made through the insertion of the possible collateral taker's contractual obligation to return the 'same' financial collateral in the provision of Article 2, pt. 2 of the FSA, is that under Croatian law the definition of TTFCA covers not only a 'true' TTFCA, but also a financial collateral arrangement in which the tradeability function of financial collateral is virtually non-existent.

It is argued that the definition of a TTFCA under Croatian FSA covers not only outright transfer of title, which is the method of provision of financial collateral in TTFCAs under which the collateral taker is obliged to provide equivalent financial collateral to collateral provider at the end of the transaction, but also fiduciary transfer of title, ${ }^{91}$ which would be the method of provision of financial collateral in TTFCAs under which the collateral taker is obliged to provide to the collateral provider the same financial collateral that was previously provided to collateral taker at the beginning of the transaction. In relation to the latter TTFCAs, it should be noted that TTFCAs that rely on such transfer of title are not covered by a security legal structure known in Croatian law as a court and notary public security of claims by transfer of right (Cro. sudsko i javnobilježničko osiguranje tražbina prijenosom prava), which is regulated by the enforcement law rules. ${ }^{92}$ This is evident from the provision of Article

\footnotetext{
90 See: Radin, op. cit. (fn. 87), p. 346; Tot, op. cit. (fn. 79), p. 1259.

91 See: Radin, op. cit. (fn. 87), p. 346; Tot, op. cit. (fn. 79), p. 1259.

92 For this type of security legal structure see, e.g., Mihelčić, G.: Sudsko i javnobilježničko osiguranje tražbina prijenosom prava vlasništva na nekretninama i pokretninama i prijenosom prava, in: Slakoper, Z. (red.), Bukovac Puvača, M. and Mihelčić, G. (eds.): Bankovni $i$ financijski ugovori, Narodne novine, Zagreb, 2017, pp. 411-412.
} 
4 (1) of FSA, which serves the transposition of the Article 3 (1) of the FCD, under which 'the validity of financial security agreement is not dependent on the performance of any formal act', such as the conclusion of the agreement in the form of a court record or a notary public act and the entry in the appropriate registry, which are the titulus and the modus aquirendi of the transfer of right under the enforcement law rules governing the court and notary public security of claims by transfer of right. Also, taking into account that the collateral taker is entitled under the FSA to 'unlimited use and dispose of' financial collateral unless stipulated otherwise in the agreement, it should be concluded that if a 'fiduciary transfer of title' is protected under the FSA, such transfer of title is definitely not the fiduciary transfer of title on the basis of the property law rules, as the right to the unlimited use and disposal of financial collateral is not compatible with fiduciary transfer of title under the property law. Rather, transfer of title in a TTFCA, under which the collateral taker is obliged to return the same financial collateral to the collateral provider, should be treated as an outright transfer of title with the establishment of a fiduciary relationship under the general rules of obligations law. ${ }^{93}$ The main features of this 'fiduciary assignment' of title to financial collateral are that: (i) the collateral provider transfers unlimited title to financial collateral to the collateral taker; (ii) the collateral taker is entitled to use financial collateral for the purpose and under the conditions agreed with the collateral provider; (iii) the collateral taker is obliged with contractual fiduciary duties to the collateral provider which are owed personally, not proprietary; (iv) the collateral taker is obliged to retransfer the financial collateral to the collateral provider. ${ }^{94}$

The effect of inclusion of fiduciary assignment of title to financial collateral in the definition of the TTFCA under the FSA is that the FSA affords the same level of protection of validity and enforceability of TTFCAs which employ a fiduciary assignment of title, as it does in relation to the TTFCAs which employ the method of an outright transfer of title. This approach unfairly favours the economic interests of collateral providers. Financial collateral agreements under which the financial collateral is provided on the basis of a fiduciary transfer of title should be treated as security financial collateral arrangements within the meaning of Article 2 (1) (c) of the FCD, and not as TTFCAs. Paradoxically, under the FSA, the collateral taker in a financial collateral arrange-

\footnotetext{
93 For transfers of title with the establishment of a fiduciary relationship under rules of the law of obligations, see, e.g., Gavella, N.: Fiducijarni prijenos i neke daljnje mogućnosti stvarnopravnog osiguranja tražbina, in: Gavella, N. (red.): Stvarno pravo - Svezak drugi, Narodne novine, Zagreb, 2007, pp. 474-475.

94 For the main features of a fiduciary assignment see, especially: Miladin, P. and Markovinović, H.: Založno pravo na pravu, Pravo u gospodarstvu, 46 (4) 2007, pp. 105-106.
} 
ment which employs the method of a fiduciary assignment of title has fewer rights to financial collateral than the collateral taker in a security financial collateral arrangement, as in the latter the collateral taker is entitled to a right of use and dispose of financial collateral under the provisions of Article 5 of the FSA.

Due to the ambiguity of the notion of a TTFCA under the FSA, the scope for unjustified recharacterisation of a TTFCA under Croatian law is undoubtedly extended. This is, inter alia, indicated by one interpretation of the provisions of FSA made in Croatian legal literature: the TTFCA was named a 'fiduciary financial security' and the title transfer method employed in a TTFCA was identified with the fiduciary transfer of title, while it was neglected that the outright transfer of title is covered with the definition of TTFCA in the Croatian law. ${ }^{95}$ As the Croatian legal literature on the topic of financial collateral arrangements is significantly scarce, the labeling of all TTFCAs as fiduciary transfers of title, in connection with the analyzed deficiencies of the notion of a TTFCA under the FSA and with the non-mandatory legal nature of provision of Article 6 (1) of the FSA, could mislead the national courts: the possibility exists that the national courts could mistakenly recharacterise even the true outright transfers of title to financial collateral as fiduciary transfers of title. Such recharacterisation would have calamitous consequences for the collateral takers, as they would be deprived of the right to use and dispose of financial collateral. It should be noted that the risk for unjustified recharacterisation of a TTFCA is yet unrealised in the Croatian court practice, as there are still no court decisions rendered relating to the application of FSA, or at least such decisions have not yet been made available to the public. However, in one published court decision relating to fiduciary transfers of title in general, the court has made a reference to the FSA as one of the laws that governs the fiduciary transfers of title under the Croatian law. ${ }^{96}$

\section{CONCLUSION}

The title transfer method for the provision of financial collateral which is employed in the TTFCAs was developed in the financial market practice with an aim to ensure the tradeability function of financial collateral. In TTFCAs this function is guaranteed only if the financial collateral is transferred to the

\footnotetext{
95 See: Ernst, H. and Matanovac Vučković, R.: Prijenos prava radi osiguranja - nedorečenosti i nedovršenosti, Zbornik Pravnog fakulteta Sveučilišta u Rijeci, 33 (1) 2012, p. 161.

96 See: Županijski sud u Splitu [County Court in Split], 16 Gž Zk-509/17-2, 28/9/2017, p. 6 , available at: Vrhovni sud Republike Hrvatske, Portal sudske prakse [https://sudskapraksa.csp. vsrh.hr/], accessed on 30/10/2018.
} 
collateral taker on the basis of an outright transfer of title, i.e. transfer of all right, title and interest in financial collateral to the collateral taker. The most common types of securities financing transactions entered in the European cross-border and domestic financial markets rely on a TTFCA, as evidenced by the provisions of the standard market agreements governing those transactions.

The validity and enforceability of TTFCAs and of the legal solutions developed in financial market practice and employed in the standard market agreements are protected by the FCD, the provisions of which are significantly influenced by the financial market practice. The recharacterisation of TTFCAs by the national courts as arrangements creating a security interest in financial collateral would deprive the financial collateral provided under a TTFCA of its important function: tradeability in the financial market. Therefore, the aim of the FCD is to eliminate the recharacterisation risk of TTFCAs as security interests.

Generally, the risk of recharacterisation of a TTFCA is minimal if participants to the securities financing transactions which rely on TTFCAs do not deviate significantly from the terms of the standard market documentation when concluding agreements that govern those transactions. The parties may increase the re-characterization risk if they insert to their agreements contractual provisions which make their agreement internally inconsistent, such as provisions which limit the collateral taker's right to freely use and dispose of financial collateral and provision which require the collateral taker to return to the collateral provider at the closing leg of the transaction the same financial collateral that was previously transferred to him at the opening leg of the transactions. In these cases, the recharacterisation by the national court of a TTFCA might be justified as such provisions indicate that the true intent of the parties was to create a security interest in financial collateral, and not to transfer the title to financial collateral outright to the collateral taker.

In view of the tradeability function of financial collateral, the provisions of the FCD relating to TTFCA should be interpreted in a manner that under the notion of a TTFCA only an outright transfer of title is covered, and not a fiduciary transfer of title. The financial collateral arrangements which rely on fiduciary transfers of title are essentially security interests and should be considered as security financial collateral arrangements under the FCD.

Unfortunately, the notion of a TTFCA contained in the Croatian FSA covers not only outright transfers of title to financial collateral but also fiduciary assignments of title to financial collateral. Due to the analysed shortcomings of the regulation of TTFCAs in the Croatian law, the risk of recharacterisation of TTFCAs is not eliminated but is moreover increased. Improper transposition 
of the FCD into Croatian law and the complexity of the financial collateral law as highly specialised field of law might mislead the national courts to an unwarranted recharacterisation of an outright transfer of title to financial collateral under a TTFCA as a fiduciary transfer of title, thereby ruling out the tradeability function of financial collateral and depriving the collateral taker of his right to use and dispose of financial collateral during the ordinary lifetime of the transaction.

Therefore, the provisions of the Croatian FSA should be amended in order to eliminate the present inconsistencies and the negative effects of the currently employed legal solutions for collateral takers, and in order to transpose the FCD properly into Croatian law. The future amendments to the FSA should include at least a deletion of a part of the provision of Article 2, pt. 2 of the FSA which provides that the collateral taker may be obliged to transfer to the collateral provider financial collateral in specie, i.e. the 'same' financial collateral that was originally provided to him at the beginning of the transaction. However, due to numerous deficiencies of the FSA, many of which were not topics of this paper, a better approach would be to adopt a new FSA which would be made from scratch.

\section{LITERATURE}

1. Akkermans, B.: The European Union Development of European Property Law, in: Godt, C. (ed.), Cross Border Research and Transnational Teaching under the Treaty of Lisbon - Hanse Law School in Perspective, Wolf Legal Publishers, Oisterwijk, 2010, pp. 39-60

2. Beale, H.: A View from England (Symposium: Reform of Security over Moveable Property), Edinburgh Law Review, 16 (2) 2012, pp. 278-282

- DOI: https://doi.org/10.3366/elr.2012.0106

3. Benjamin, J.: Financial Law, Oxford University Press, Oxford/New York, 2007

4. Bridge, M. and Braithwaite, J.: Private Law and Financial Crises, Journal of Corporate Law Studies, 13 (2) 2013, pp. 361-399

- DOI: https://doi.org/10.5235/14735970.13.2.361

5. Choudhry, M.: The Repo Handbook, Butterworth-Heinemann, Oxford, 2010

- DOI: https://doi.org/10.1016/C2009-0-16714-4

6. Comotto, R.: A Guide to Best Practice in the European Repo Market - ICMA European Repo and Collateral Council - December 2017, International Capital Market Association, Zurich, 2017

7. Devos, D.: The Directive 2002/47/EC on Financial Collateral Arrangements of June 6, 2002, in: Vandersanden, G. and De Walsche, A. (eds.): Mélanges en 
hommage à Jean-Victor Louis - volume II, Editions de l'Université de Bruxelles, Bruxelles, 2003, pp. 259-279

8. Ernst, H. i Matanovac Vučković, R.: Prijenos prava radi osiguranja - nedorečenosti i nedovršenosti, Zbornik Pravnog fakulteta Sveučilišta u Rijeci, 33 (1) 2012, pp. 145-186

9. Fabozzi, F. J. and Mann, S. V.: Repurchase and Reverse Repurchase Agreements, in: Fabozzi, F. J. and Mann, S. V. (eds.), Securities Finance - Securities Lending and Repurchase Agreements, John Wiley \& Sons, Hoboken, 2005, pp. 221-240

10. Faulkner, M. C.: An Introduction to Securities Lending, in: Fabozzi, F. J. and Mann, S. V. (eds.): Securities Finance - Securities Lending and Repurchase Agreements, John Wiley \& Sons, Hoboken, 2005, pp. 3-37

11. Gavella, N.: Fiducijarni prijenos i neke daljnje mogućnosti stvarnopravnog osiguranja tražbina, in: Gavella, N. (red.): Stvarno pravo - Svezak drugi, Narodne novine, Zagreb, 2007, pp. 469-565

12. Gretton, G. L.: Financial Collateral and the Fundamentals of Secured Transactions, Edinburgh Law Review, 10 (2) 2008, pp. 209-238

- DOI: https://doi.org/10.3366/elr.2006.10.2.209

13. Haentjens, M. and de Gioia-Carabellese, P.: European Banking and Financial Law, Routledge, London/New York, 2015

- DOI: https://doi.org/10.4324/9781315708515

14. Hudson, A.: The Law on Financial Derivatives, Sweet \& Maxwell, London, 2006

15. Johansson, E.: Property Rights in Investment Securities and the Doctrine of Specificity, Springer, Berlin/Heidelberg, 2009

- DOI: https://www.doi.org/10.1007/978-3-540-85904-8

16. Keijser, T. R. M. P.: A Need for a Change: The Undesirable Consequences of the Settlement Finality Directive and the Collateral Directive in the Field of Property and Insolvency Law, in Particular for Small-and Medium-Sized Enterprises, Zeitschrift für Europäisches Privatrecht, 13 (2) 2006, pp. 308-325

- DOI: http://dx.doi.org/10.2139/ssrn.2859451

17. Keijser, T. R. M. P.: Financial Collateral Arrangements: The European Collateral Directive Considered from a Property and Insolvency Law Perspective, Kluwer, Deventer, 2006

- DOI: http://dx.doi.org/10.2139/ssrn.2859072

18. Lefter, C. and Duagi, G.: The Fiduciary Guarantee in the Romanian and European Legal Context, Juridical Tribune, 6 (2) 2016, pp. 103-116

19. Lomnicka, E.: Financing Devices Involving the Transfer or Retention of Title, in: Beale, H., Bridge, M., Gullifer, L. and Lomnicka, E.: The Law of Security and Title-Based Financing, Oxford University Press, Oxford, 2018, p. 261-333 
20. Mäntysaari, P.: The Law of Corporate Finance: General Principles and EU Law - Volume II: Contracts in General, Springer, Berlin/Heidelberg, 2010

- DOI: https://doi.org/10.1007/978-3-642-03055-0

21. Markovinović, H. and Tepeš, N.: Posebno o pripadnosti nematerijaliziranih vrijednosnih papira povjerenih u skrbništvo, in: Slakoper, Z. (red.), Bukovac Puvača, M. and Mihelčić, G. (eds.): Bankovni i financijski ugovori, Narodne novine, Zagreb, 2017, pp. 978-995

22. Mihalina, E.: Ekonomski aspekti repo posla, in: Slakoper, Z. (red.), Bukovac Puvača, M. and Mihelčić, G. (eds.): Bankovni i financijski ugovori, Narodne novine, Zagreb, 2017, pp. 1279-1304

23. Mihelčić, G.: Sudsko i javnobilježničko osiguranje tražbina prijenosom prava vlasništva na nekretninama i pokretninama i prijenosom prava, in: Slakoper, Z. (red.), Bukovac Puvača, M. and Mihelčić, G. (eds.): Bankovni i financijski ugovori, Narodne novine, Zagreb, 2017, pp. 380-439

24. Miladin, P. and Markovinović, H.: Založno pravo na pravu, Pravo u gospodarstvu, 46 (4) 2007, pp. 95-146

25. Moreno, H. S.: Towards a European System of Property Law, European Review of Private Law, 19 (5) 2011, pp. 579-611

26. Murray, E.: Financial Collateral Arrangements and the Financial Markets, in: Dahan, F. (ed.): Research Handbook on Secured Financing in Commercial Transactions, Edward Elgar Publishing, Cheltenham/Northampton, 2015, pp. 286-325

- DOI: https://doi.org/10.4337/9781781001844.00020

27. Radin, D.: Hrvatski pravni okvir financijskog osiguranja, in: Miladin, P. and Jakšić, T. (eds.): Prilagodba hrvatskog prava i ekonomije europskom tržištu kapitala, Pravni fakultet Sveučilišta u Zagrebu, Zagreb, 2013, pp. 331-386

28. Saguato, P.: The Liquidity Dilemma and the Repo Market: A Two-Step Policy Option To Address the Regulatory Void, Stanford Journal of Law, Business, and Finance, 22 (1) 2017, LSE Legal Studies Working Paper No. 21/2015, available at SSRN [https://ssrn.com/abstract=2812173], accessed on 15/09/2018

29. Schindler, C. and Hindelang, M.: Praxishandbuch Repos und Wertpapierdarlehen, Springer Gabler, Wiesbaden, 2016

- DOI: https://doi.org/10.1007/978-3-8349-4023-0

30. Sigman, H. C. and Kieninger, E.: The Law of Assignment of Receivables: in Flux, Still Uncertain, Still Non-Uniform, in: Sigman, H. C. and Kieninger, E.: Cross-Border Security over Receivables, Sellier, Munich, 2009, pp. 1-82

- DOI: https://doi.org/10.1515/9783866538597.1

31. Slakoper, Z.: Ugovor o zajmu, in: Slakoper, Z. (red.), Bukovac Puvača, M. and Mihelčić, G. (eds.): Bankovni i financijski ugovori, Narodne novine, Zagreb, 2017, pp. 528-564 
32. Stadler, V. and Lanoo, K.: The EU Repo Markets: The Need for Full Integration, Centre for European Policy Studies, Brussels, 2000

33. Tarnanidou, C. I.: EU Financial Collateral Arrangements and Re-Hypothecation in the Shadow of 'Shadow Banking': To Further Regulate or Not?, Journal of Banking Regulation, 17 (3) 2016, pp. 200-238

- DOI: https://doi.org/10.1057/jbr.2014.22

34. Tot, I.: Financial Market lex mercatoria and its Influence on the Financial Collateral Directive, InterEULawEast: Journal for the International and European Law, Economics and Market Integrations, 5 (1) 2018, pp. 37-72

- DOI: https://doi.org/10.22598/iele.2018.5.1.3

35. Tot, I.: Repo ugovor, in: Slakoper, Z. (red.), Bukovac Puvača, M. and Mihelčić, G. (eds.): Bankovni i financijski ugovori, Narodne novine, Zagreb, 2017, pp. 12371278

36. Yeowart, G. and Parsons, R., with Murray, E. and Patrick, H.: Yeowart and Parsons on the Law of Financial Collateral, Edward Elgar Publishing, Cheltenham/ Northampton, 2016

- DOI: https://doi.org/10.4337/9781782546320

\section{LEGISLATION}

1. Directive 2002/47/EC of the European Parliament and of the Council of 6 June 2002 on financial collateral arrangements (OJ L 168, 27/6/2002)

2. Directive 2009/44/EC of the European Parliament and of the Council of 6 May 2009 amending Directive 98/26/EC on settlement finality in payment and securities settlement systems and Directive 2002/47/EC on financial collateral arrangements as regards linked systems and credit claims (OJ L 146, 10/6/2009)

3. Directive 2014/59/EU of the European Parliament and of the Council of 15 May 2014 establishing a framework for the recovery and resolution of credit institutions and investment firms and amending Council Directive 82/891/EEC, and Directives 2001/24/EC, 2002/47/EC, 2004/25/EC, 2005/56/EC, 2007/36/EC, 2011/35/EU, 2012/30/EU and 2013/36/EU, and Regulations (EU) No 1093/2010 and (EU) No 648/2012, of the European Parliament and of the Council (OJ L 173, $12 / 6 / 2014)$

4. Regulation (EU) 2015/2365 of the European Parliament and of the Council of 25 November 2015 on transparency of securities financing transactions and of reuse and amending Regulation (EU) No 648/2012 (OJ L 337, 23/12/2015)

5. Zakon o financijskom osiguranju [Financial Security Act] (NN no. 76/07, 59/12)

6. Zakon o obveznim odnosima [Obligations Act] (NN no. 35/05, 41/08, 125/11, $78 / 15,29 / 18)$

7. Zakon o tržištu kapitala [Capital Market Act] (NN no. 65/18) 


\section{MARKET DOCUMENTATION}

1. ACI Croatia/Hrvatska udruga banaka: Okvirni ugovor o reotkupu financijskih instrumenata (okvirni repo ugovor) - verzija 2014, ACI Croatia/Hrvatska udruga banaka, Zagreb, 2014

2. ACI Croatia/Hrvatska udruga banaka: Dodatak I Okvirnog ugovora o reotkupu financijskih instrumenata (okvirnog repo ugovora) - verzija 2014, ACI Croatia/ Hrvatska udruga banaka, Zagreb, 2014

3. ACI Croatia/Hrvatska udruga banaka: Okvirni ugovor za transakcije izvedenim financijskim instrumentima - verzija 2008, ACI Croatia/Hrvatska udruga banaka, Zagreb, 2008

4. International Securities Lending Association: Global Master Securities Lending Agreement - Version: January 2010 - Update: July 2012, London, 2012

5. International Swaps and Derivatives Association, Collateral Reform Group: Collateral Arrangements in the European Financial Markets - The Need for National Law Reform, International Swaps and Derivatives Association, London, 2000

6. Securities Industry and Financial Markets Association, and International Capital Market Association: Global Market Repurchase Agreement - 2011 version, Washington/Zurich, April 2011

7. Securities Industry and Financial Markets Association, and International Capital Market Association: Global Market Repurchase Agreement (2011 version) - Buy/ Sell Back Annex - Supplemental Terms and Conditions for Buy/Sell Back Transactions, Washington/Zurich, March 2012 